\title{
Pembuatan Bioetanol Dari Ampas Tahu Dengan Metode Hidrolisis Asam Dan Fermentasi Dengan Menggunakan Ragi Instan
}

\author{
Production of Bioethanol from Tofu by Product with Fermentation using Instant \\ Yeast and Acid Hydrolysis Method
}

\author{
Nanti Musita \\ Balai Riset dan Standardisasi Industri Bandar Lampung \\ Jl by pass Soekarno Hatta KM 1 Rajabasa \\ E-mail : nantimusita@gmail.com
}

\begin{abstract}
Abstrak
Dewasa ini, kebutuhan energy dunia semakin meningkat sementara persediaan energy dari bahan bakar fosil yang selama ini diandalkan jumlahnya terbatas. Oleh karena itu, diperlukan sumber energy alternatif yang mampu mengatasi krisis energi tersebut. Salah satu sumber energy alternative yang sedang dikembangkan adalah bioetanol. Bioetanol dapat diproduksi dengan cara fermentasi glukosa menggunakan ragi Saccharomyces cerevisiae. Produksi etanol dalam penelitian ini menggunakan bahan dasar ampas tahu. Penelitian ini bertujuan untuk mendapatkan konsentrasi asam sulfat optimum pada proses hidrolisa dan waktu fermentasi optimum pada proses pembuatan bioetanol dari ampas industri tahu. Hasil penelitian menunjukkan bahwa konsentrasi asam sulfat yang optimum untuk menghidrolisa ampas tahu yaitu pada konsentrasi 0,5 M selama 30 menit pada suhu $121^{\circ} \mathrm{C}$. Selama fermentasi berlangsung terjadi penurunan $p H$ dan glukosa serta peningkatan produksi etanol. Produksi etanol optimum terjadi pada lama fermentasi 5 hari dengan konsentrasi etanol $4,77 \% \mathrm{~b} / \mathrm{b}$.
\end{abstract}

Kata kunci: ampas tahu, ragi instan,bioetanol, hidrolisis.

\begin{abstract}
Today, world energy needs are increasing while the supply of energy from fossil fuels that has been relied on is limited. Therefore, an alternative energy source is needed that is able to overcome the energy crisis. One alternative energy source that is being developed is bioethanol. Bioethanol can be produced by fermenting glucose using Saccharomyces cerevisiae yeast. Ethanol production in this study uses tofu waste material. This study aims to obtain the optimum concentration of sulfuric acid in the hydrolysis process and optimum fermentation time in the process of making bioethanol from tofu industry. The results showed that the optimum concentration of sulfuric acid for hydrolyzing tofu waste was at a concentration of $0.5 \mathrm{M}$ for 30 minutes at $121^{\circ} \mathrm{C}$. During fermentation there is a decrease in $\mathrm{pH}$ and glucose and an increase in ethanol production. The optimum ethanol production occurs at 5 days fermentation time with $4.77 \%$ ethanol concentration $b / b$.
\end{abstract}

Keywords: tofu pulp, instant yeast, bioethanol, hydrolysis.

\section{Pendahuluan}

Bahan baku untuk produksi bioethanol cukup melimpah di Indonesia. Produksi bioetanol di berbagai Negara telah dilakukan dengan menggunakan bahan baku yang berasal dari hasil pertanian dan perkebunan (Sarjdoko,1991). Oleh karena itu dilakukan upaya mencari bahan baku alternatif lain yang bernilai ekonomis rendah untuk pembuatan etanol. Bahan selulosa memiliki potensi sebagai bahan baku alternatif pembuatan etanol.

Salah satu contohnya adalah ampas tahu yang merupakan limbah industri tahu. Ketersediaan ampas tahu cukup besar, menurut data Kementrian Perindustrian kurun waktu 2010-2013 terdapat trend peningkatan jumlah 
industri tahu di Indonesia sebesar 1,4\% (Kemenperin. 2019).

Limbah industri tahu biasanya dibagi menjadi 2 bentuk yaitu limbah cair dan limbah padat. Limbah padat berupa hasil pembersihan kedelai (batu, tanah, kulit dan benda lain) sekitar $0,3 \%$ dan sisa saringan bubur kedelai yang disebut ampas/onggok tahu dari sekitar 25-35\% dari produk tahu yang dihasilkan (Kaswinarni, 2007). Di dalam limbah padat tahu tersebut masih mengandung selulosa sekitar 42-49\%, sehingga dapat dipertimbangkan sebagai bahan baku pembuatan bioetanol.

Dalam industri pangan, termasuk limbah indutri tahu dapat menimbulkan masalah bagi lingkungan jika tidak dikelola karena masih mengandung sejumlah besar karbohidrat, protein, lemak, garam-garam mineral dan sisasisa bahan kimia yang digunakan dalam pengolahan dan pembersihan (Jenie dan Rahayu, 1990). Berdasarkan potensi yang terdapat pada limbah padat industri tahu, pemanfaatan kedua jenis limbah padatnya berpotensi sebagai bahan baku pembuatan bioetanol.

Salah satu tahapan dalam produksi bioetanol dari bahan baku selulosa adalah proses hidrolisis. Proses hidrolisis dengan asam dapat dikelompokkan menjadi hidrolisis asam pekat dan hidrolisis asam encer (Taherzadeh and Karimi, 2007), dan masingmasing mempunyai kelebihan dan kekurangan.

Secara keseluruhan, konversi selulosa menjadi etanol ditunjukkan menurut rekasi sebagai berikut:

1. Tahap Pemurnian selulosa

$$
\text { Ampas tahu } \stackrel{\mathrm{NaOH} .}{\longrightarrow} \text { Selulosa }
$$

2. Tahap Hidrolisis Selulosa

$$
\left(\mathrm{C}_{6} \mathrm{H}_{10} \mathrm{O}_{5}\right) \mathrm{n}+\mathrm{n} \mathrm{H} \mathrm{H}_{2} \mathrm{O} \stackrel{\mathrm{H}_{2} \mathrm{SO}_{4}}{\longrightarrow} \mathrm{n}\left(\mathrm{C}_{6} \mathrm{H}_{12} \mathrm{O}_{6}\right)
$$

3. Tahap Fermentasi

\section{S.cerevisiae}

$$
\left(\mathrm{C}_{6} \mathrm{H}_{12} \mathrm{O}_{6}\right) \longrightarrow 2 \mathrm{C}_{2} \mathrm{H}_{5} \mathrm{OH}+2 \mathrm{CO}_{2}
$$

Penelitian ini bertujuan memanfaatkan limbah padat industri tahu (ampas tahu) sebagai bahan baku pembuatan bioetanol, menentukan kondisi operasi terbaik pada proses hidrolisis berdasarkan konsentrasi glukosa tertinggi melalui pengkajian terhadap variabel operasi berupa rasio bahan baku, dan menentukan kadar etanol yang dihasilkan melalui proses fermentasi.

\section{Metode Penelitian}

Penelitian dan analisa ini dilakukan di laboratorium uji Baristand Lampung.

Bahan-bahan yang digunakan adalah limbah padat/ampas dari industri tahu, ragi instan (merk Instant Succes), $\mathrm{H}_{2} \mathrm{SO}_{4}$, reagent DNS, dan bahan kimia lain.

Alat-alat yang digunakan adalah neraca analitik, pH meter, piknometer, shaker incubator, autoklaf, spektofotometer UV Vis, oven, dan alat analisa lainnya.

Pada penelitian ini, proses hidrolisa dilakukan dengan 5 taraf konsentrasi $\mathrm{H}_{2} \mathrm{SO}_{4}$ yaitu 0,1 M, 0,2 M, 0,3 M, 0,4 M,dan 0,5 M.

\section{Pelaksanaan Penelitian}

\section{Pembuatan tepung ampas tahu}

Pengeringan dan penggilingan onggok untuk mendapatkan tepung ampas tahu. Tepung tersebut kemudian dianalisa, kadar air, abu,pati, serat kasar, protein,dan lemak menggunakan metode SNI Cara Uji Makanan dan Minuman (SNI 01-2891-1992) (BSN, 1992).

\section{Proses hidrolisa asam.}

Hidrolisa tepung ampas tahu dengan larutan $\mathrm{H}_{2} \mathrm{SO}_{4}$ konsentrasi $0,1 \mathrm{M}, 0,2 \mathrm{M}, 0,3 \mathrm{M}$, 0,4 M, dan 0,5 M, dengan perbandingan $1: 10$ $\mathrm{b} / \mathrm{v}$ menggunakan outoklaf pada suhu $121^{\circ} \mathrm{C}$ selama 30 menit pada tekanan 1atm. Hasil hidrolisa kemudian disaring. Filtrat hasil saringan dianalisa $\mathrm{pH}$ dan kadar glukosanya (menggunakan metode DNS).

\section{Fermentasi etanol.}

Filtrat tersebut kemudian dinetralkan dengan $\mathrm{Ca}(\mathrm{OH})_{2}$ sampai $\mathrm{pH}$ mencapai 5-6, kemudian ditambahkan urea dan NPK 1\%, $\left(\mathrm{NH}_{4}\right)_{2} \mathrm{HPO}_{4} 0,1 \%$, ragi instant $5 \%$. Kemudian ditutup rapat dengan sumbat kapas dan ditempatkan dalam alat shaker incubator selama 1-5 hari pada suhu $30^{\circ} \mathrm{C}$ kecepatan $150 \mathrm{rpm}$. Selama fermentasi dilakukan pengamatan terhadap bau, $\mathrm{pH}$ menggunakan $\mathrm{pH}$ meter 
menggunakan pH meter, kadar etanol menggunakan piknometer dan kadar glukosa pada $0,1,3$, dan 5 hari proses fermentasi.

\section{Pengamatan}

Pengamatan terhadap tepung ampas tahu meliputi kadar air, abu, protein, lemak, pati, dan serat kasar. Pengamatan pada hasil fermentasi meliputi $\mathrm{pH}$, etanol dan glukosa. Kemudian data disajikan secara deskriptif dalam bentuk tabel dan grafik.

\section{Hasil Dan Pembahasan \\ Kadar Proksimat Tepung Ampas Tahu}

Tepung ampas tahu yang dipergunakan pada penelitian ini berasal dari ampas tahu basah yang dikeringkan selama 2-3 hari, digiling kemudian di ayak, sehingga diperoleh tepung yang halus (Gambar 1).

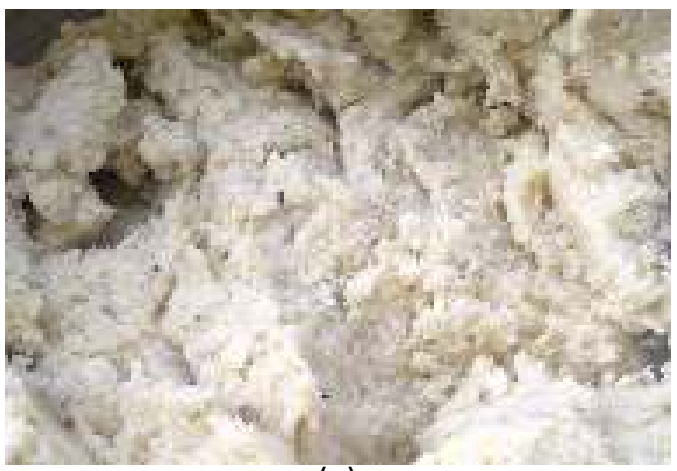

(a)

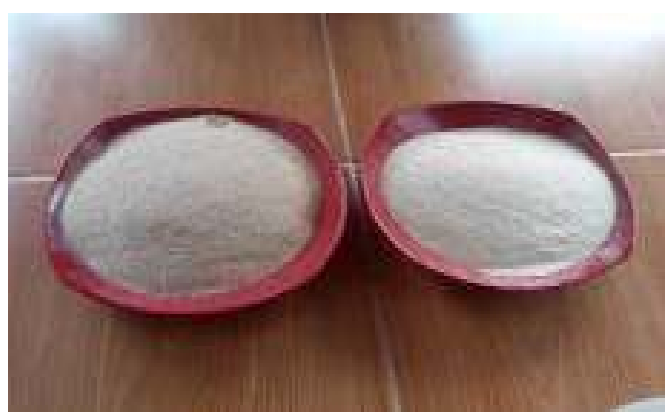

(b)

Gambar 1. Ampas tahu basah (a) dan tepung ampas tahu (b).

Gambar 1 memperlihatkan ampas tahu yang masih basah pada gambar sebelah kiri dan gambar sebelah kanan adalah tepung ampas yang putih dan bersih dengan tekstur yang cukup lembut yang dihasilkan setelah melalui proses pengeringan dan penggilingan.

Tepung ampas tahu kemudian dianalisa kadar proksimatnya yang dibandingkan dengan hasil analisa dari peneliti lain sebagai perbandingan (Tabel 1).

Tabel 1 Hasil analisa tepung ampas tahu dengan data pembanding ampas basah dan ampas kering

\begin{tabular}{|l|c|c|c|}
\hline Kompon & Jumlah & Ampas & Ampas \\
\hline Air & 4,37 & - & - \\
\hline Abu & 3,85 & 0,58 & 4,58 \\
\hline Protein & 21,56 & 2,91 & 23,39 \\
\hline Lemak & 8,73 & 1,39 & 9,96 \\
\hline Pati & 24,54 & - & - \\
\hline Serat & 17,82 & 3,76 & 19,44 \\
\hline Bahan & - & 14,69 & 88,35 \\
\hline
\end{tabular}

Keterangan : *Suprapti, 2005

Tabel 1 menunjukkan bahwa kadar proksimat ampas tahu pada penelitian ini masih mengandung pati dan serat kasar yang cukup besar. Keadaan ini mendukung penggunaan ampas tahu sebagai bahan baku pembuatan bioetanol.

Kacang kedelai terkenal dengan nilai gizinya yang kaya. Kacang kedelai merupakan sumber protein lengkap dan merupakan salah satu makanan yang mengandung 8 asam amino yang penting dan diperlukan oleh tubuh manusia. Kandungan gizi kacang kedelai adalah protein $30-40 \%$, lemak 15 - 20\%, karbohidrat $30-35 \%$, dan abu atau mineral 3 $5 \%$. Ampas tahu kering mempunyai protein $23,39 \%$, lemak $9,96 \%$, serat $19,44 \%$, abu $4,58 \%$ (Suprapti,2005).

\section{Proses Hidrolisa Asam}

Proses fermentasi didahului dengan proses hidrolisa asam selama 30 menit pada suhu $121^{\circ} \mathrm{C}$ tekanan $1 \mathrm{~atm}$ dengan autoklaf. Pada penelitian ini menggunakan asam sulfat $\left(\mathrm{H}_{2} \mathrm{SO}_{4}\right)$ dengan konsentrasi0,1 M,0,2 $\mathrm{M}, 0,3 \mathrm{M}, 0,4 \mathrm{M}$, dan 0,5 M. Hasil hidrolisa kemudian diamati $\mathrm{pH}$,dan kadar glukosa $(\mathrm{mg} / \mathrm{ml})$ seperti terlihat pada Gambar 2 di bawah ini.

Pada gambar 2 menunjukkan kadar glukosa cenderung mengalami peningkatan dengan peningkatan konsentrasi $\mathrm{H}_{2} \mathrm{SO}_{4}$, yang berbanding terbalik dengan penurunan nilai pH.Kadar glukosa pada keseluruhan proses hidrolisa tertinggi $1,8398 \mathrm{mg} / \mathrm{ml}$ yang berasal dari penggunaan $\mathrm{H}_{2} \mathrm{SO}_{4}$ sebesar 0,5 M. Jadi 
penggunaan $\mathrm{H}_{2} \mathrm{SO}_{4} 0,5 \mathrm{M}$ menghasilkan glukosa paling tinggi dibandingkan konsentrasi lainnya.

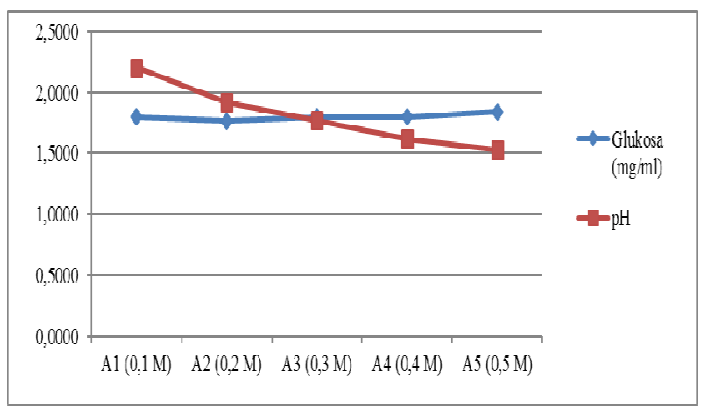

Gambar 2. Hasil analisa ampas tahu setelah proses hidrolisis dengan $\mathrm{H}_{2} \mathrm{SO}_{4}$

Jumlah $\mathrm{H}_{2} \mathrm{O}$ dalam larutan $\mathrm{H}_{2} \mathrm{SO}_{4} 0,1 \mathrm{M}$, 0,2 M, 0,3 M dan 0,4 M lebih banyak dari konsentrasi $0,5 \quad M \quad$ sehingga berpengaruh terhadap viskositas larutan yang dihidrolisis. Semakin besar viskositas larutan, tumbukan antar reaktan menjadi berkurang sehingga reaksi berjalan lebih lambat. Hal ini disebabkan $\mathrm{H}_{2} \mathrm{SO}_{4}$ berfungsi sebagai katalis, sehingga semakin besar konsentrasi katalis maka semakin cepat pula reaksi berlangsung yang akan menghasilkan kadar glukosa yang besar. Katalis berguna untuk mempercepat jalannya reaksi hidrolisa dimana yang berpengaruh terhadap kecepatan reaksi adalah ion H-nya (Fengel and Wegener, 1995).

Menurut Hafid et al (2017), perlakuan awal (pretreatment) perlu dilakukan dalam proses pembuatan bioetanol dari biomassa berupa limbah pertanian ataupun sampah organik karena untuk meningkatkan kemampuan proses hidrolisis asam ataupun enzim. Pretreatment bertujuan untuk mengubah atau merusak struktur dari komponen penyusun pada biomassa tersebut sehingga memudahkan enzim untuk menghidrolisis menjadi monomermonomer gula (Hafid et al., 2017). Metode pretreatment mengacu pada proses pelarutan dan pemisahan satu atau lebih komponenkomponen dari bahan (biomassa) sehingga pada ikatan komponen bahan tersebut menjadi longgar dan memudahkan bahan kimia ataupun biologi masuk kemudian menguraikannya.

\section{Fermentasi Etanol}

Tahap selanjutnya adalah proses fermentasi menggunakan ragi instant sebagai sumber mikrobanya. Fermentasi dilakukan selama lima hari dan dilakukan pengamatan kadar etanol, pH, dan glukosa (Gambar 3 - 5).
Gambar 3 - 5 menunjukkan perubahan kadar glukosa dan tingkat keasaman ampas tahu yang semakin berkurang dengan bertambahnya konsentrasi $\mathrm{H}_{2} \mathrm{SO}_{4}$ dan lama fermentasi. Bentuk perubahan tersebut berbanding terbalik dengan perubahan kadar etanol hasil fermentasi ampas tahu.

Dalam proses pembuatan bioetanol dari limbah pertanian ada beberapa faktor yang berpengaruh untuk mendapatkan etanol yang optimal antara lain suhu, pH, waktu inkubasi, konsentrasi substrat, beban mikroba dan akumulasi byproduct (Zabed et al., 2017).

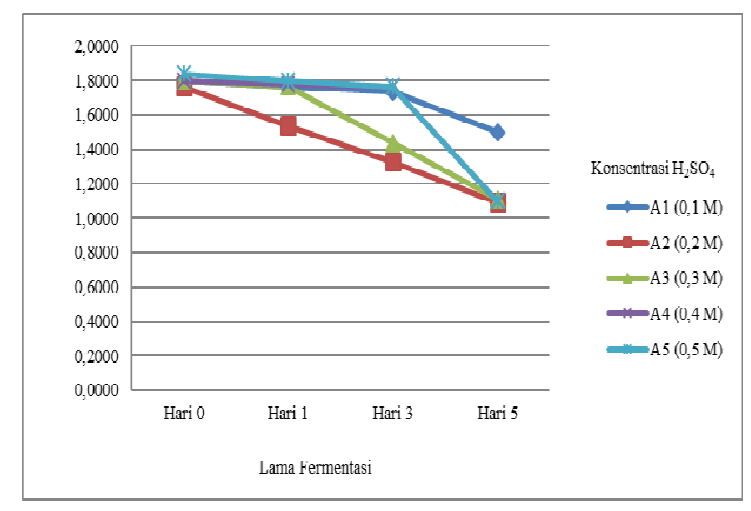

Gambar 3. Perubahan kadar glukosa $(\mathrm{mg} / \mathrm{ml})$ selama fermentasi ampas tahu pada berbagai konsentrasi $\mathrm{H}_{2} \mathrm{SO}_{4}$

Gambar 3 menunjukkan perubahan kadar glukosa selama fermentasi, yaitu terjadi penurunan sejak hari pertama fermentasi dan pada hari ke tiga penurunan glukosa semakin besar. Sisa gula terfermentasi cenderung makin sedikit dengan semakin lamanya proses fermentasi. Semakin rendah konsentrasi gula pada substrat awal, makin rendah pula jumlah sisa gula di dalam setiap volumenya

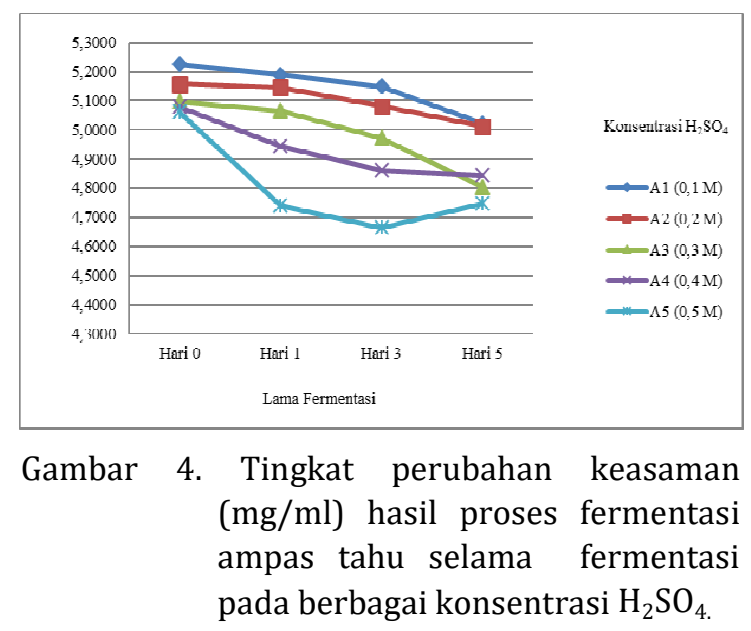


Pada Gambar 4 menunjukkan perubahan $\mathrm{pH}$ media selama proses fermentasi. Penurunan $\mathrm{pH}$ secara nyata nampak setelah hari ketiga fermentasi.

Tingkat keasaman atau $\mathrm{pH}$ medium merupakan salah satu faktor penting yang mempengaruhi pertumbuhan mikroorganisme dan pembentukan produk dalam proses fermentasi karena setiap mikroorganisme mempunyai kisaran $\mathrm{pH}$ optimal. Dalam proses fermentasi terjadi penurunan. Perubahan $\mathrm{pH}$ dalam fermentasi disebabkan karena dalam aktivitasnya sel khamir selain menghasilkan etanol sebagai metabolit primer juga menghasilkan asam-asam organik seperti asam malat, asam tartarat, asam sitrat, asam laktat, asam asetat, asam butirat dan asam propionate sebagai hasil sampingan. Asam-asam ini menurunkan pH medium (Sugiharto, 1991). pH pada proses hidrolisis dan fermentasi menjadi penting karena enzim atau mikroba akan dapat hidup optimal pada $\mathrm{pH}$ tertentu, seperti enzim selulase pada pH 4,5-5, Saccharomyces cerevisiae dapat menghasilkan etanol dengan optimal pada pH 4 - 5 dan Zimomonas mobilis optimal pada pH 5 - 6 (Zabed et al., 2017).

Dari Gambar 5, pada saat hari kelima fermentasi menunjukkan konsentrasi etanol tertinggi. Hal ini disebabkan karena ketersediaaan nutrisi pada medium masih cukup besar. Semakin tinggi konsentrasi substrat dibutuhkan waktu yang semakin lama, karena gula yang ada meningkatkan pertumbuhan mikroba untuk pembentukan sel dan memperlama proses penghasilan etanol, sehingga meningkatkan biaya recovery selanjutnya (Zabed et al., 2017).

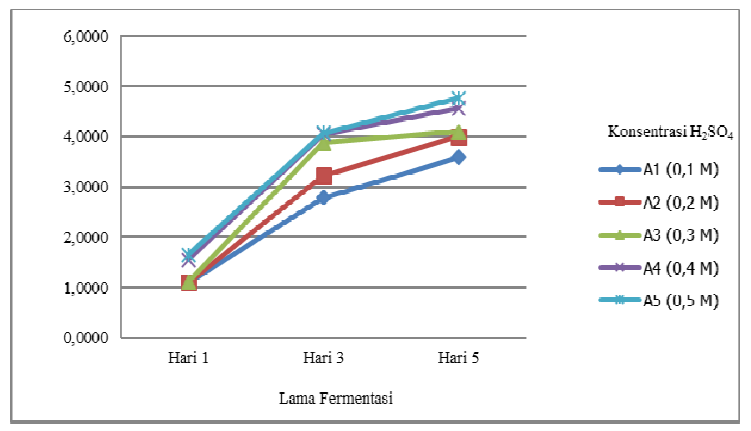

Gambar 5. Perubahan kadar etanol (\%) selama proses fermentasi ampas tahu pada berbagai konsentrasi $\mathrm{H}_{2} \mathrm{SO}_{4}$
Fermentasi alkohol atau alkoholisasi adalah proses perubahan gula menjadi alcohol dan $\mathrm{CO}_{2}$ oleh mikroba, terutama oleh khamir Saccharomyces cerevisiae. Karbohidrat akan dipecah dahulu menjadi gula sederhana yaitu hidrolisis pati menjadi unit-unit glukosa. Selanjutnya gula terfermentasi oleh Saccharomyces cerevisiae akan diubah menjadi alkohol dan gas $\mathrm{CO}_{2}$ sebagian lagi akan berubah menjadi massa khamir. Apabila diperhatikan maka antara jumlah gula terfermentasi dengan produksi alkohol berbanding lurus.

Dalam tahap pertama fermentasi glukosa selalu terbentuk asam piruvat melalui jalur Embden Meyerhof Parnas (EMP) atau glikolisis. Piruvat tersebut diubah menjadi alkohol melalui dua tahap yaitu pertama, piruvat didekarboksilasi menjadi asetaldehid oleh piruvat dekarboksilase dengan melibatkan tiamin pirofosfat dan tahap kedua asetaldehid oleh alkoholdehidrogenase direduksi dengan $\mathrm{NADH}_{2}$ menjadi alkohol (Sutiari, 1983).

\section{Kesimpulan}

1. Konsentrasi asam sulfat yang optimum untuk menghidrolisa ampas tahu yaitu pada konsentrasi $0,5 \mathrm{M}$ selama 30 menit pada suhu $121^{\circ} \mathrm{C}$.

2. Selama fermentasi berlangsung terjadi penurunan $\mathrm{pH}$ dan glukosa serta peningkatan produksi etanol.

3. Produksi etanol optimum terjadi pada lama fermentasi 5 hari dengan konsentrasi etanol $4,77 \% \mathrm{~b} / \mathrm{b}$.

\section{Daftar Pustaka}

Fengel, D. and G. Wegener G.1995. Kayu: Kimia, Ultrastruktur, Reaksi-reaksi. Terjemahan : Gajah ada University Press.: Yogyakarta.

Hafid, H. S., N.A.A. Rahman, U. K. M. Shah, A.S. Baharuddin, dan A.B. Ariff. 2017. Feasibility of Using Kitchen Waste as Future Substrate for Bioethanol Production: A review. Renewable and Sustainable Energy Reviews, 74:671686.

https://doi.org/10.1016/j.rser.2017.02 .071

Jenie, B.S.L. dan W.P. Rahayu. 1990. Penanganan Limbah Industri Pangan. Penerbit Kanisius. Yogyakarta

Joeh, Tina. 1998, SteamExploson of Cotton Gin Waste for Fuel Ethanol Production, Jurnal Kimia. 
Kaswinarni, F. 2007. Kanjian Teknis Pengolahan Limbah Padat dan Cair Industri Tahu. Tesis. PS Ilmu Lingkungan, Universitas Diponegoro, Semarang.

Kementerian Perindustrian RI. 2019. Data Industri Kecil Menengah. Jakarta.

Sarjdoko.1991. Bioteknologi Latar Belakang dan Beberapa Penerapannya. Jakarta: Gramedia Pustaka Umum

Sugiharto, P.E. 1991. Analisis Kuantitatif Kadar Etanol Dari Bonggol Pisang oleh Saccharomyces cerevisiae. Fakultas MIPA, Universitas Brawijaya, Malang

Suprapti. 2005. Pembuatan Tahu. Edisi Teknologi Pengolahan Pangan.Yogyakarta. Kanisius.
Sutiari. 1983.Produksi Alkohol dari Daging dan Kulit Pisang. Universitas Brawijaya, Malang.

Taherzadeh, M.J. and Karimi, K. 2007 Acid-Based Hydrolysis Processes for Ethanol from Lignocellulosic Materials: A Review. Bio Resources, 2, 472-499.

Zabed, H., J. N.Sahu, A. Suely, A.N. Boyce, dan G. Faruq. 2017. Bioethanol Production from Renewable Sources: Current Perspectives and Technological Progress. Renewable and Sustainable Energy Reviews, 71: 475-501. https://doi.org/10.1016/j.rser.2016.12. 076. 